Journal of Computational Acoustics, Vol. 24, No. 4 (2016) 1699001 (3 pages)

(c) IMACS

DOI: $10.1142 / \mathrm{S} 0218396 \mathrm{X} 16990010$

\title{
Author Index Volume 24 (2016)
}

Abusag, N. M. and Chappell, D. J., On sparse reconstructions in near-field acoustic holography using the method of superposition

Ainslie, M. A., Ellis, D. D. and Harrison, C. H., Low frequency bottom reverberation in a Pekeris waveguide with Lambert's rule

Bareille, O., see Ben Souf, M. A.

Ben Souf, M. A., Chronopoulos, D., Ichchou, M., Bareille, O. and Haddar, M., On the variability of the sound transmission loss of composite panels through a parametric probabilistic approach

Besset, S., see Troian, R.

Calvo, D. C., see Woolfe, K.

Calvo, D. C., see Woolfe, K.

Casalis, G., see Pascal, L.

Chappell, D. J., see Abusag, N. M.

Cho, Y., see Li, W.

Choo, Y., Seong, W. and Lee, K., Efficient algorithm for long-range monostatic reverberation in shallow water using geometrical ray-bundle

Chronopoulos, D., see Ben Souf, M. A.

Collins, M. D., see Woolfe, K.

Collins, M. D., see Woolfe, K.

Deng, M., see Li, W.

Deü, J.-F., see Serra, Q.

Ellis, D. D., see Ainslie, M. A.

Gillot, F., see Troian, R.

Goodrich, M., see Reilly, S. M.

Grigorieva, N. S., Kupriyanov, M. S., Stepanova, D. A., Ostrovskiy, D. B. and Seleznev, I. A., Pulse scattering on an ice sphere submerged in a homogeneous waveguide covered with ice

Guo, Z., see Xie, J.

Haddar, M., see Ben Souf, M. A.

Han, H.-S., see Metwally, M. K.

Han, S. M., see Metwally, M. K.

Harrison, C. H., see Ainslie, M. A.

Ichchou, M. N., see Serra, Q.

Ichchou, M., see Ben Souf, M. A.

Jeon, H. J., see Metwally, M. K.

Kim, T.-S., see Metwally, M. K.

Kupriyanov, M. S., see Grigorieva, N. S.

Ladevèze, P., see Li, H.

Lee, K., see Choo, Y.

Lemoine, G. I., see Ou, M.-J. Y.

Li, H., Ladevèze, P. and Riou, H., Hybrid finite element method and variational theory of complex rays for Helmholtz problems

24, 3 (2016) 1650009

24, 2 (2016) 1650001

24, 1 (2016) 1550018

24, 1 (2016) 1550018

24, 2 (2016) 1650006

24, 3 (2016) 1650019

24, 4 (2016) 1650022

24, 1 (2016) 1550015

24, 3 (2016) 1650009

24, 3 (2016) 1650011

24, 2 (2016) 1650002

24, 1 (2016) 1550018

24, 3 (2016) 1650019

24, 4 (2016) 1650022

24, 3 (2016) 1650011

24, 2 (2016) 1550020

24, 2 (2016) 1650001

24, 2 (2016) 1650006

24, 1 (2016) 1650007

24, 4 (2016) 1650014

24, 2 (2016) 1650005

24, 1 (2016) 1550018

24, 1 (2016) 1650003

24, 1 (2016) 1650003

24, 2 (2016) 1650001

24, 2 (2016) 1550020

24, 1 (2016) 1550018

24, 1 (2016) 1650003

24, 1 (2016) 1650003

24, 4 (2016) 1650014

24, 4 (2016) 1650015

24, 2 (2016) 1650002

24, 1 (2016) 1550017

24, 4 (2016) 1650015 
Li, J. H. and Liu, Q. H., Fast frequency-domain forward and inverse methods for acoustic scattering from inhomogeneous objects in layered media

$\mathrm{Li}, \mathrm{M}$. and $\mathrm{Lu}, \mathrm{H}$., Reconstruction of interior sound fields of vibrating shells with an open spherical microphone array

Li, W., Deng, M. and Cho, Y., Cumulative second harmonic generation of ultrasonic guided waves propagation in tube-like structure

Li, X.-Y., see Yan, H.

Liu, H., see Xie, J.

Liu, H., see Yan, H.

Liu, Q. H., see Li, J. H.

Liu, Q. H., see Xie, J.

Liu, S., see Ma, L.

$\mathrm{Lu}, \mathrm{H}$. , see Li, M.

Luo, W., see Yang, C.

Lyu, L., see Yang, C.

Ma, L., Qiao, G. and Liu, S., Erratum - A combined doppler scale estimation scheme for underwater acoustic OFDM system

Maréchal, R., see Perrey-Debain, E.

Metwally, M. K., Han, H.-S., Jeon, H. J., Nam, S. B., Han, S. M. and Kim, T.-S., Influence of skull anisotropic mechanical properties in low-intensity focused ultrasound

Marburg, S., The Burton and Miller method: Unlocking another mystery of its coupling parameter

Mimani, A. and Munjal, M. L., Acoustic end-correction in a flow-reversal end chamber muffler: A semi-analytical approach

Munjal, M. L., see Mimani, A.

Nam, S. B., see Metwally, M. K.

Ostrovskiy, D. B., see Grigorieva, N. S.

Ou, M.-J. Y. and Lemoine, G. I., Time-harmonic analytic solution for an acoustic plane wave scattering off an isotropic poroelastic cylinder: Convergence and form function

Pascal, L., Piot, E. and Casalis, G., A new implementation of the extended Helmholtz resonator acoustic liner impedance model in time domain CAA

Perrey-Debain, E., Maréchal, R. and Ville, J.-M., A special boundary integral method for the numerical simulation of sound propagation in flow ducts lined with multi-cavity resonators

Piot, E., see Pascal, L.

Potty, G. R., see Reilly, S. M.

Qiao, F., see Yang, C.

Qiao, G., see Ma, L.

Rdzanek, W. J., see Rdzanek, W. P.

Rdzanek, W. P., Rdzanek, W. J. and Szemela, K., Sound radiation of the resonator in the form of a vibrating circular plate embedded in the outlet of the circular cylindrical cavity

Reilly, S. M., Potty, G. R. and Goodrich, M., Computing acoustic transmission loss using 3D Gaussian ray bundles in geodetic coordinates

Riou, H., see Li, H.

Seleznev, I. A., see Grigorieva, N. S.

Seong, W., see Choo, Y.

Serra, Q., Ichchou, M. N. and Deü, J.-F., On the use of transfer approaches to predict the vibroacoustic response of poroelastic media

Shimoyama, K., see Troian, R.

Shin, Y. S., see Woo, H.

24, 3 (2016) 1650008

24, 4 (2016) 1650013

24, 3 (2016) 1650011

24, 4 (2016) 1650016

24, 2 (2016) 1650005

24, 4 (2016) 1650016

24, 3 (2016) 1650008

24, 2 (2016) 1650005

24, 1 (2016) 1692001

24, 4 (2016) 1650013

24, 1 (2016) 1550019

24, 1 (2016) 1550019

24, 1 (2016) 1692001

24, 3 (2016) 1650012

24, 1 (2016) 1650003

24, 1 (2016) 1550016

24, 2 (2016) 1650004

24, 2 (2016) 1650004

24, 1 (2016) 1650003

24, 4 (2016) 1650014

24, 1 (2016) 1550017

24, 1 (2016) 1550015

24, 3 (2016) 1650012

24, 1 (2016) 1550015

24, 1 (2016) 1650007

24, 1 (2016) 1550019

24, 1 (2016) 1692001

24, 4 (2016) 1650018

24, 4 (2016) 1650018

24, 1 (2016) 1650007

24, 4 (2016) 1650015

24, 4 (2016) 1650014

24, 2 (2016) 1650002

24, 2 (2016) 1550020

24, 2 (2016) 1650006

24, 1 (2016) 1550021 
Siegmann, W. L., see Woolfe, K.

24, 3 (2016) 1650019

Siegmann, W. L., see Woolfe, K.

Stepanova, D. A., see Grigorieva, N. S.

24, 4 (2016) 1650022

24, 4 (2016) 1650014

Szemela, K., see Rdzanek, W. P.

Troian, R., Shimoyama, K., Gillot, F. and Besset, S., Methodology for the design of the geometry of a cavity and its absorption coefficients as random design variables under vibroacoustic criteria

Ville, J.-M., see Perrey-Debain, E.

Woo, H. and Shin, Y. S., Analysis of acoustic-structure interaction using a high-order doubly asymptotic approximation

Woolfe, K., Collins, M. D., Calvo, D. C. and Siegmann, W. L., Seismo-acoustic benchmark problems involving sloping fluid-solid interfaces

Woolfe, K., Collins, M. D., Calvo, D. C. and Siegmann, W. L., Seismo-acoustic benchmark problems involving sloping solid-solid interfaces and variable topography

Xiao, P. and Yang, K.-d., Temporal coherence of acoustic signal transmissions in a fluctuating deep ocean

Xie, J., Guo, Z., Liu, H. and Liu, Q. H., Reverse time migration using the pseudospectral time-domain algorithm

Yan, H., Yang, L., Li, X.-Y. and Liu, H., Acoustic VTI modeling using an optimal time-space domain finite-difference scheme

Yang, C., Luo, W., Zhang, R., Lyu, L. and Qiao, F., An efficient coupled-mode formulation for acoustic propagation in inhomogeneous waveguides

Yang, K.-d., see Xiao, P.

Yang, L., see Yan, H.

Zhang, R., see Yang, C.

24, 4 (2016) 1650018

24, 2 (2016) 1650006

24, 3 (2016) 1650012

24, 1 (2016) 1550021

24, 4 (2016) 1650022

24, 3 (2016) 1650019

24, 3 (2016) 1650010

24, 2 (2016) 1650005

24, 4 (2016) 1650016

24, 1 (2016) 1550019

24, 3 (2016) 1650010

24, 4 (2016) 1650016

24, 1 (2016) 1550019 